\title{
Teachers' Competencies for the Implementation of Educational Offers in the Field of Education for Sustainable Development
}

\author{
Franziska Bertschy ${ }^{1, \dagger}$, Christine Künzli ${ }^{2, *, \dagger}$ and Meret Lehmann ${ }^{2, \dagger}$
}

1 Institute for Pre-Primary and Primary Education IVP NMS, University of Teacher Education Berne, Waisenhausplatz 29, Berne-BE 3000, Switzerland; E-Mail: franziska.bertschy@nms.phbern.ch

2 School for Teacher Education, Institute for Pre-Primary and Early Primary Education, University of Applied Sciences and Arts Northwestern Switzerland, FHNW, Obere Sternengasse 7, Solothurn-SO 4502, Switzerland; E-Mail: meret.lehmann@fhnw.ch

$\dagger$ These authors contributed equally to this work.

* Author to whom correspondence should be addressed; E-Mail: christine.kuenzli@fhnw.ch; Tel.: +41-326-286-674.

Received: 27 September 2013; in revised form: 19 November 2013 / Accepted: 20 November 2013 / Published: 28 November 2013

\begin{abstract}
The term of education is an integral part of any programmatic political document on sustainable development. This fact underlines the significance that is assigned to education in the context of sustainable development. It leads to the question of what competencies teachers need in order to develop and implement educational offers in the field of Education for Sustainable Development (ESD) so that they can aspire to and attain specific educational goals with their students. This touches on the question of the building of corresponding competencies in teacher education and further education. So far, few attempts have been made to describe teachers' competencies regarding ESD and to develop corresponding competence models. The following article presents two models-Curriculum, Sustainable Development, Competences, Teacher Training (CSCT Model) and Learning for the future: The Competences in Education for Sustainable Development (ECE Model)—and discusses their benefit for teacher education and further education. These models differ in how broadly they define ESD and in what audiences they target at. This comparison shows and explains why competence models should focus on profession-specific core competencies if they are to be used as a basis for the conception of educational offers in the field of ESD in education and further education of teachers. The drawn conclusion consists in initial considerations for the conception of another competence model.
\end{abstract}


Keywords: Education for Sustainable Development; teacher competencies; CSCT-Model; ECE-Model

\section{Introduction}

Education and, more specifically, school as an institution play a leading role in the implementation of sustainable development. The term education appears in nearly all programmatic documents on sustainable development both on an international and a national level. Education for Sustainable Development (ESD) even increasingly enters official school curricula (cf. for example the two linguistically regional curricula in Switzerland: the "plan d'études romand" [1] and the "Lehrplan 21 der deutschsprachigen Schweiz" [2]). Rather than a subject on its own, ESD is usually considered an interdisciplinary matter that is brought to schools' attention. This educational objective claims to foster children and adolescents' ability to take part in establishing sustainable development [3-6]). Studies show that the implementation of sustainable development is highly demanding for teachers and that it requires specific knowledge and abilities [7,8].

At a teacher level, this means that they need specific content knowledge as well as pedagogical content knowledge for the implementation of ESD. Both of these forms of teacher knowledge are crucial for successful learning at school and thus a part of professional action competency. Studies by Kunter et al. [9] have shown this for Mathematics - it can be assumed that the same applies to teaching in other subjects.

With regard to ESD, the question is thus what exactly this professional action competency is which teachers need in order to effectively implement Education for Sustainable Development (ESD), i.e., to actually foster children's and adolescents' ability to participate in establishing sustainability. The question of the competencies is one of the most fundamental pedagogical issues besides the question of how to approach the development of competencies and the question of appropriate learning settings [10]. In order to answer the questions of the what (learning settings) and the how (the approach when developing competencies) there needs to be an analysis of the what for. For that reason the article at hand focuses on this question.

The following shortly outlines two common competence models, which describe educators' competencies [11]. These two models - the Curriculum, Sustainable Development, Competences, Teacher Training (CSCT) model [12] as well as the Learning for the future: The Competences in Education for Sustainable Development (ECE) model [13] — are currently the only elaborate models to describe ESD specific competencies of teachers [14]. Both models claim for themselves to have answered the question of teachers' competencies for implementing ESD. They could therefore serve as a basis for the conception of educational offers in institutions for teacher education. The following article shall critically examine these competence models regarding their respective benefits in this matter.

\section{The CSCT Competence Model}

The CSCT model [12] is supposed to enable the development of educational offers for all school levels by assembling all competencies teachers are required in this matter. It is a product of the 
international organization ENSI (Environment and School Initiatives); it is considered a Comenius-2 project and was developed through collaboration of members of fifteen European Universities [15].

The CSCT competence model focuses on the teacher as an individual, as an agent in an educational institution and a member of a certain society. Competencies should enable teachers in these three fields to foster sustainable development. This means that the competencies even touch on the realm of a teacher's personal and social behavior, which should serve sustainable development. Therefore, the model incorporates a teacher's whole personality in the matter of sustainable development, rather than just his or her "professional self".

This model sees ESD in the context of the challenge of living in a risk society and summarizes the subordinate educational goals referring to Klafki's definition of "Allgemeinbildung" [16] and referring to Elmose and Roth [17] in general educational objectives as:

- The competency to understand and change one's own living conditions.

- The competency to participate in collective decisions.

- The competency to be solidary with those who are-for various reasons - unable to control their own life conditions.

The enabling of people to autonomous, critical thinking is included in the educational objective of ESD as a central, general goal of education. Critical thinking should enable people to question their own lifestyle even with regard to the claim of sustainability, which implies that they need to be able, i.e., to be enabled, to understand and critically reflect the claim of sustainable development.

The CSCT model explicitly avoids turning ESD into another educational concept (adjectival education) in the sense of existing concepts like environment education, peace education etc. Rather, it emphasizes the claim of a more comprehensive educational incentive whose aim is to take into account the high complexity of sustainable education by means of a holistic approach. In our view, the model expresses an interesting thought in the context of educational goals: It is the authors' opinion that, on the one hand, specific competencies for a conscious implementation of ESD educational goals are required. On the other hand, however, these competencies could also serve as an innovation to educational offers in general [18]. They could thereby contribute to the educational relevance of school in general.

The model distinguishes three superordinate dimensions of competence (overall competences; cf. Figure 1): teaching/communicating; reflecting/visioning; networking. The three superordinate dimensions contain five competence domains: knowledge, systems-thinking, emotions, values and ethics, action [12].

All five sections comprise statements and declarations of skills [19] that correspond to the three superordinate dimensions. At the same time, interactions and interconnections between the individual domains are pointed out. However, the distinction between the five domains of competency is rather vague and unconvincing in parts. For example, the domain "emotions" is problematic as emotions play a role as a concomitant in all the other domains, and the claim of its teachability or learnability, which is central when it comes to education, is particularly questionable in this domain, as well as in the domain of "values and ethics".

As mentioned before, teachers are not only regarded as professionals, but also as individuals with civic responsibilities and as role models with a public educational function, which makes it necessary that they be qualified in these areas. Nevertheless, the fostering of personal behavior and desirable public 
commitment regarding sustainable development cannot be an integral part of the teacher professionalization process, and thus it cannot be the task of teacher education institutions (cf. in more detail below) [20,21]. In a comprehensive sense, the model defines competencies which should serve the ambitious fostering and implementation of sustainable development. Mindful of the doable, it acknowledges that the desirable skills mentioned in the model must be present in a collective rather than in a single person [12]. However, in education and further education of teachers the development of competencies is consistently designed for and targeted at individuals only. Thus, even though the CSTC model offers comprehensively defined competencies, there remains a considerable need for clarification when it comes to the core competencies for planning and implementing concrete educational offers in the context of ESD taught by an individual teacher. With regard to this, it needs to be clarified what competencies should be targeted in offers for teacher education and further education of teachers.

Figure 1. Curriculum, Sustainable Development, Competences, Teacher Training (CSCT) competence model ([12], p. 26).

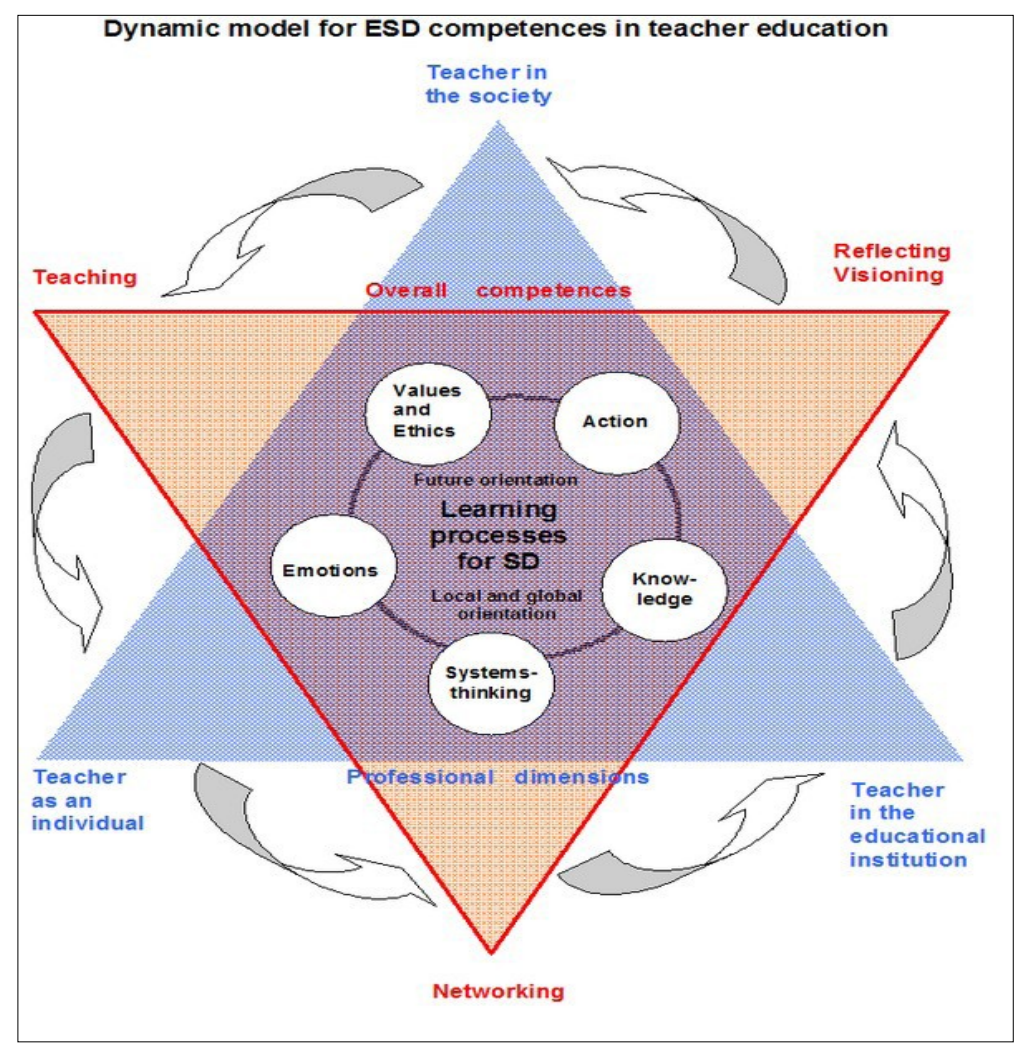

All five sections comprise statements and declarations of skills [19] that correspond to the three superordinate dimensions. At the same time, interactions and interconnections between the individual domains are pointed out. However, the distinction between the five domains of competency is rather vague and unconvincing in parts. For example, the domain "emotions" is problematic as emotions play a role as a concomitant in all the other domains, and the claim of its teachability or learnability, which is central when it comes to education, is particularly questionable in this domain, as well as in the domain of "values and ethics".

As mentioned before, teachers are not only regarded as professionals, but also as individuals with civic responsibilities and as role models with a public educational function, which makes it necessary 
that they be qualified in these areas. Nevertheless, the fostering of personal behavior and desirable public commitment regarding sustainable development cannot be an integral part of the teacher professionalization process, and thus it cannot be the task of teacher education institutions (cf. in more detail below) [20,21]. In a comprehensive sense, the model defines competencies which should serve the ambitious fostering and implementation of sustainable development. Mindful of the doable, it acknowledges that the desirable skills mentioned in the model must be present in a collective rather than in a single person [12]. However, in education and further education of teachers the development of competencies is consistently designed for and targeted at individuals only. Thus, even though the CSTC model offers comprehensively defined competencies, there remains a considerable need for clarification when it comes to the core competencies for planning and implementing concrete educational offers in the context of ESD taught by an individual teacher. With regard to this, it needs to be clarified what competencies should be targeted in offers for teacher education and further education of teachers.

\section{The ECE Competence Model}

In 2012, an international group of experts created another competence catalogue whose target audience is educators in general rather than teachers only. It aims at the integration of ESD in caretaking and educational institutions (taking into account all functions of education in the context of sustainable development).

The ECE model [13] should serve politics, institutional development and educational tasks as an orientation aid to foster development towards sustainability. It aims at people, groups and institutions with multiplier function regarding the implementation of sustainable development, and it particularly aims at educators of teachers, too. Lesson design and development of concrete educational offers in terms of teaching specific competencies for sustainable development are included but not central to the model.

No educational goals that should be attained through corresponding educational offers are introduced. By means of recommendations to regional, national and international politics, to decision makers in private business vocational training, to teachers, to educational institutions of all levels, to the people in charge of curricula and teaching materials as well as to quality managers, the model aims to support the efficacy of the suggested competencies and to raise awareness that the societal task of sustainable development has to be tackled by society as a whole. The above-mentioned are thus the main addressees of this competence model.

The competence catalogue aims to confine itself to feasible core competencies, and the authors point to the fact that competencies are not to be regarded as minimal standards but rather as guidelines. Even individual educators, who are not solely regarded in the focus of their "professional selves" in this model either, should be able to orient themselves by these competencies.

With regard to ESD, four domains-so-called competence fields-define what the educator:

- understands... and

- is able to...; and that they

- work with others in ways that... and

- should learn to be (the educator is someone who...).

The four competence fields are compartmentalized according to the three target domains below [13]: 
Holistic approach: Networked, integral thinking, taking complexity into account

Envisioning change: Learning from the past, inspired acting in the present, taking into account visions and alternatives for the future, exploring new avenues and co-creating them.

Achieving transformation: Change in educators' attitudes and actions, implementing new goals and practicing new procedures, implementing reorientation and alignment of the educational system towards sustainability on all levels.

Each of the target fields is allotted some briefly described competencies in the above-mentioned four fields learning to know, learning to do, learning to live and learning to be.

The broadly defined competence catalogue is considered a suggestion for meeting the societal task of sustainable development on different levels and in different areas of public life. In its claim, it explicitly exceeds what would qualify an individual educator to align his or her teaching to the objective of ESD. For example, it is about the “...development of one's personal attributes and ability to act with greater autonomy, judgment and personal responsibility in relation to sustainable development..." ([13], p. 13). Or: The educator "...is motivated to make a positive contribution to other people and their social and natural environment, locally and globally" ([13], p. 15). As declared in the context of the CSCT model, change in one's personal behavior and lifestyle (how they should live/how they should be) towards sustainability cannot be the objective of teacher education institutions, whose focus must lie with the core of professional life, the preparation, enactment and implementation of instruction [22]. This includes that teachers in training need to (critically) delve into the idea of sustainability and reflect their values. This is an important prerequisite for implementing ESD. However, it is pivotal that these reflections in teacher training are explicitly understood with regard to implementing ESD rather than implementing SD. Departing from these considerations, it is only to a limited extend that the ECE model too is suitable as a basis for the conception of educational and further educational offers.

\section{Discussion and Implications}

The following shall offer a summarizing discussion about the meaning of the two competence models for teacher education in the field of ESD, that is in what way they could be a basis for the conception and implementation of entire degree courses or single courses: The two competence models CSCT [12] and ECE [13] underline the demanding task of giving effect to the educational objective of ESD on several levels in society. They reveal that the vision of, pedagogization "of sustainable development in social politics cannot be the sole means for its implementation: ESD depends on a, supportive environment" ([23], p. 9), and it is always meant as one measure among numerous others: It [...] would involve all of society's stakeholders to work collaboratively and in partnership..." ([24], para. 23). Furthermore, they show that people in the context of sustainable development are addressed both as professionals and as individuals with civic responsibilities. The latter field relies particularly on those competencies that all human beings need in order to participate in the idea of sustainable development. These competencies are not profession specific, which means that the competence catalogues of ESD apply (cf. for example [3-6]). The models thus show that effects can only be expected if complimentary and intertwined measures are taken on all levels of society. Both competence models thus entail areas that go above and beyond the competencies that are conveyed in teacher education. They particularly exceed the central requirement for the profession of a teacher, namely "the didactic preparation and 
implementation of teaching" ([25], p. 29). In teacher education, these comprehensive competence catalogues would have to be reduced to the question of professionalization. Institutions for teacher education have the mandate to support their teachers' professionalization processes. Professionalization refers to those domains, which are crucial for a person to successfully pursue his or her vocation and which affect students' learning in a positive manner. These domains can be drawn from the pedagogical core purposes as well as from the requirement structure that can be deducted from them. Only these are to be taken into account for the conception of study courses for example. With regard to ESD, this means that one should focus on those action competencies that are necessary for a teacher to design lessons that fosters students' ability to take part in the establishing of sustainable development. The fostering of concrete behavior and desirable public engagement with respect to sustainable development does not pertain to the professionalization process of teachers, even though it might be a legitimate objective in a given case. It can thus neither be the business of teacher education institutions [20,21].

Furthermore, the thoroughly defined competencies are only rarely tested on their learnability and controllability, respectively. At the same time, the acknowledgement of the complexity of the matter through most comprehensive competence catalogues (as seen particularly in the CSCT model) raises the risk of paralysing forces instead of stimulating and using them purposefully. Furthermore, the two models barely refer to the profession-specific discourse in Educational Science and are thus only moderately compatible with it as well as with competence models from other disciplines.

The drawn conclusion consists in initial considerations for the conception of another competence model and they shall be outlined in the following. The model shall explicitly focus on the teachers' profession-specific competencies with regard to lesson design in the interests of ESD. In our opinion, this focus on issues of effective ESD teaching is also a requirement and basis for the design of offers for education and further education if they are to qualify teachers for the planning, implementation and evaluation of educational offers in ESD, i.e., for the alignment of teaching in the interest of ESD. In this regard, two functions of education in the context of sustainable development are of importance: Education in the sense of conveying specific competencies for sustainable development on the one hand; the function of education as a means for the implementation of concrete goals of sustainable development on the other. The former function entails those competencies that should be fostered in students so that they can participate in establishing sustainable development (referring to ESD 2 by Vare and Scott [26]). This entails educational goals such as self-accountability, judgment, critical faculty, etc. The teacher's task is to offer learning opportunities to foster these competencies. Many of the specified goals of sustainable development - such as improved cultivation of natural resources - can only be implemented if the people who are to implement them have sufficient knowledge and ability to do so. Within this second function, the United Nations expect education to serve the acquisition of competencies that are required for example to attain the goals of sustainable development in a society that are recorded in Agenda 21. From this point of view, education is primarily a means of implementing specified goals of sustainable development (referring to ESD 1 by Vare and Scott [26]). The competencies that need to be conveyed according to this function can be drawn from specified goals and measures of sustainable development (cf. [27] for this distinction). The conveying of specific competencies (cf. first-mentioned function above) is the purpose of institutions for general education since they are oriented towards superordinate educational goals rather than the pursuit of concrete changes in behavior [28-30]. In the context of the last-mentioned function of "conveying competencies 
for the implementation of concrete goals of sustainable development", educational institutions thus contribute pre-eminently to the attaining of specified goals of sustainable development by enabling their learners. Educational offers must thus be aligned with such specified goals of sustainable development (and the fields of action they entail) as they are recorded for example in Agenda 21, in national strategies, in the United Nations Millennium Development Goals or in similar documents. However, such an alignment of the desired competencies cannot be reconciled with currently accepted notions of general education [28-30], according to which education is not considered to be instrumental, after all [31]. Therefore, this function of education in the context of sustainable development is aimed only at educational institutions, which, besides a general educational mandate also have a vocational one [32]. Thus, these institutions need to ask themselves how members of their vocational community or profession, respectively, can and must contribute to particular specified goals of sustainable development, and also what competencies are to be conveyed in a study course or educational offer, respectively.

The considerations presented below focus on the teacher's profession in the context of the above-mentioned second function with an eye to another competence model.

\section{ESD-Specific Professional Action Competence of Teachers in Kindergarten and Primary School}

The reflections outlined below point towards the development of a competence model for "ESD-specific professional action competency of teachers in Kindergarten and Primary School" [33]. They are being developed in the context of the research project ZMiLe [34] and pre-eminently target teacher education institutions. The competence model is meant to serve as a basis for the development of further educational offers as well as for coaching for advanced professionalization of teachers. In addition, it is supposed to be a foundation for educational offers in basic ESD training. Preceding considerations have led to the following requirements for the competence model: Central components of ESD-specific professional action competence are defined, which should enable and qualify teachers to design educational offers in ESD as well as to implement and evaluate them. The verbalization of this competence component is not aligned with specific competencies in ESD in general. Instead, it is exclusively guided by profession-specific competencies, which need to be described for different professions for the attainment of sustainable development; here for teachers (cf. above and [27]).

Firstly, the model reveals the underlying understanding of sustainable development, of education and ESD (see Künzli David and Bertschy [5] and [35]), to which ESD-specific professional action competence of teachers should refer.

ESD teaching offers, whose development and efficient implementation requires ESD-specific professional action competence of teachers, focuses on the following general goals for students:

It is the task of the teacher to foster the students' aptitude:

- for the analysis of the regulative idea of sustainable development and its concretization,

- for the thinking about the meaning of sustainable development for oneself, for one's own and the global society,

- for the development and evaluation of visions and alternative life designs and their implementation,

- for the negotiation and justification of decisions that are relevant for sustainability. 
This model is to assume that teachers already have a general professional action competence, or that it is being developed in the course of their training, and that it only needs specification with regard to ESD.

It takes Baumert and Kunter's [20,25] model of "professional action competence for teachers" as a structural basis. On the one hand, this model was chosen in order to incorporate specific action competence into professional academic discourse, as required by ESD, and in order to keep this competence discussable in this context. On the other hand, Baumert and Kunter's [20,25] model is explicitly designed as a generic model, which lends itself for specification and concretization, which has proven itself in studies on action competence of teachers and which can show empirical evidence [36].

Baumert and Kunter's competence model is based mostly on Shulman's [37-39] and Bromme's [22] theoretical works on teachers' professional knowledge, and it also refers to the US American approach by the "National Board for Professional Teaching Standards (NBPTS)" [21]. The term of professional action competence was coined by Weinert as a transfer of the idea of competence to the coping with vocational demands. Action competence is regarded as an interaction of knowledge and ability; competence in the narrow sense, with motivational, value- and conviction-oriented and self-regulative components, which act as a crucial condition for the willingness to act (cf. Figure 2, [40]).

Figure 2. Model of professional action competence ([20], p. 482) with competence aspects (for example "motivation") and competence fields (for example "content knowledge").

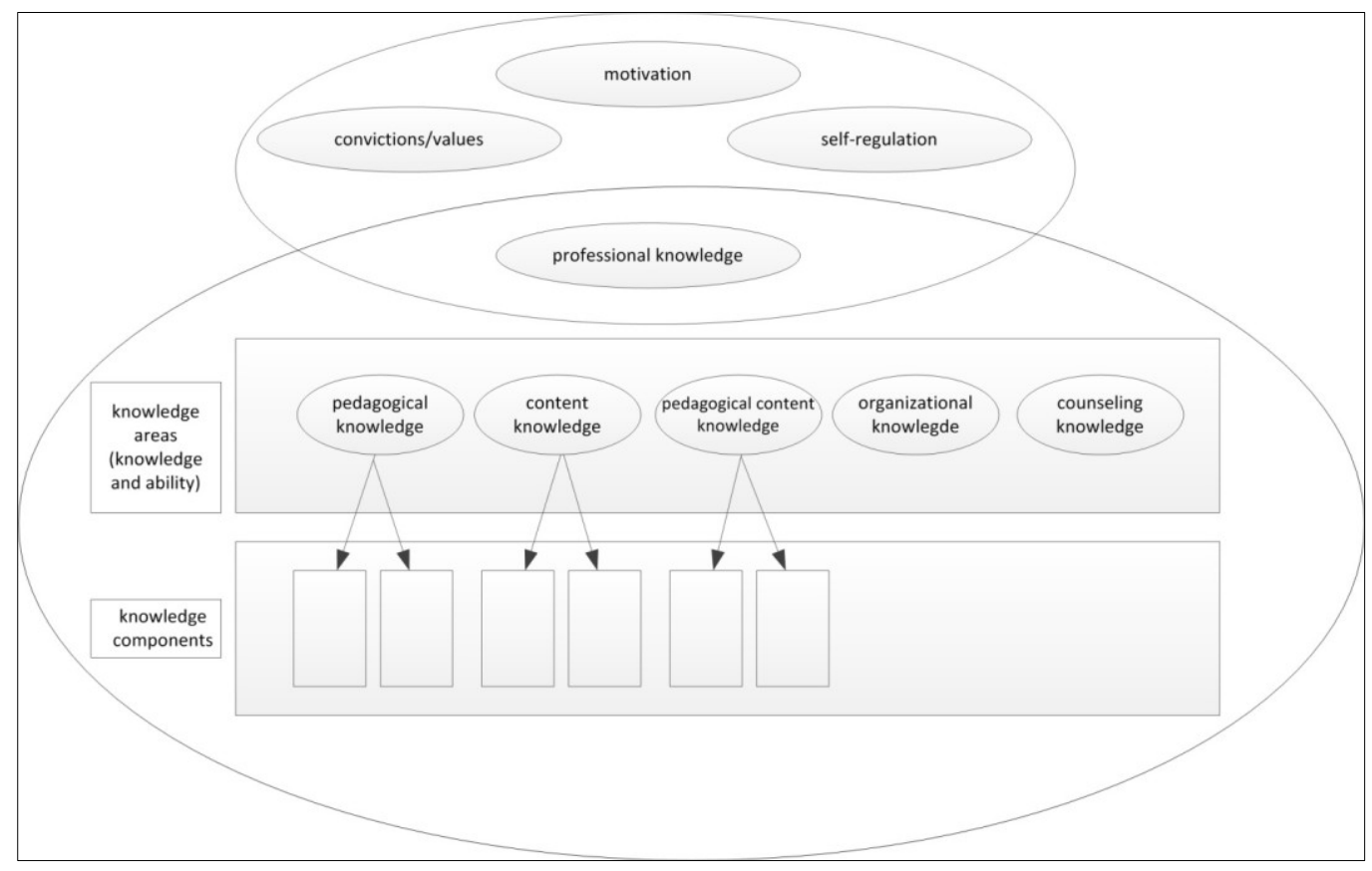

By and large, the model "ESD-specific professional action competence of teachers in kindergarten and primary school" is to meet the following requirements:

- Practical relevance for the planning, implementation and evaluation of ESD teaching,

- Ability to be contextualized in a theoretical framework,

- Classification ability (in terms of more or less intensively distinct and manifest - but also (and particularly for professional newcomers) in the sense of a reduced number of competence components),

- Discussion of teachability and learnability of the described standards. 
Following the structural basis provided by Baumert and Kunter [20] this model shall distinguish two competence aspects, which are pivotal for the design of educational offers in teacher education institutions: The aspect of convictions/values - motivation - self-regulation: Motivation and volition and the aspect knowledge and ability. These two aspects are allocated particularizing competence components along the approved dimensions of professional knowledge [25]:

ESD competence aspect motivation and volition

This refers to competence components such as:

- Acknowledgement of the importance of the regulative idea of sustainable development as a task and a challenge for society as a whole.

- Acknowledgement of the role of education as a resource for the tackling of this societal task.

- Acknowledgement of ethical judgment as an educational goal and as a central part of the co-creation competency that students should develop.

\section{ESD competence aspect knowledge and ability [41]}

With regard to ESD teaching, the two sub-aspects "content knowledge" and "pedagogical content knowledge" play a central role in this competence aspect. In general, this is about ESD-specific professional action competence, which needs to be acquired, and about ESD-specific knowledge as well as a corresponding pedagogical approach.

Examples of competence components of this sub-aspect are:

- Ability to choose possible teaching topics and to evaluate their aptitude for ESD regarding their economic, ecological, social and cultural design as well as their relevance for sustainability (pedagogical content knowledge).

- Ability to make economic, ecological, social and cultural perspectives graspable and accessible to the students within a chosen topic and by means of questions as well as formulations of problems and tasks (pedagogical content knowledge).

- Ability to recognize conflicts of goals and interests of agents in a field relevant to ESD, and the knowledge and ability to constructively cope with them (content knowledge).

- Ability to appropriately confront leaners with conflicts of goals and interests, and the ability to enable and guide their attempts at constructive coping with them (pedagogical content knowledge).

- Knowledge of participative processes and process steps (content knowledge).

- Ability to develop and provide efficient learning opportunities concerning the qualification for participation (pedagogical content knowledge).

The feasible components of the two sub-aspects both individually are to serve as a standard for ESD-specific professional action competence of teachers. They are then to be described and justified more specifically. The claim for classification ability is to be satisfied on the one hand by defining the attainable standard of the required component, and on the other hand by clarifying differentiations. Learnability and teachability of action competence as a whole is an inalienable requirement of education and further education. It is to be defined and discussed for each component. It is only after such considerations that one can — and must — aim to clarify the pedagogical question of appropriate learning settings and the approach for acquiring professional action competency. 


\section{Conclusions}

We consider it a crucial contribution to the efficacy of ESD that teachers receive a targeted qualification for ESD teaching through corresponding educational and further educational offers. At the same time, with regard to the development of ESD-specific educational offers in teacher education and further education we consider it inalienable that concrete competence components for the planning, implementation and evaluation of ESD teaching offers be justified, defined and described in a substantiating manner. In addition, the competence model ESD-specific action competence of teachers in kindergarten and primary school should aim to specifically contribute to the discussion of teacher professionalization in educational science. The actual implementation of ESD in teacher education cannot be granted, even though descriptions and justifications of professional action competency for teaching of ESD have carved out the desired destination route, and even though the discussion on its teachability and learnability could have implications for the design of educational settings in teacher education. Studies point to various impediments in the implementation of ESD in higher education: On the one hand, the disciplinary structuring of the courses [42] aggravate its implementation as it would require opportunities for interdisciplinary work. On the other hand, the significance of ESD has not been acknowledged throughout (by lecturers as well as institutions as a whole). The combination with a repeatedly stated lack in duration of training [43] renders these two barriers particularly difficult to overcome. For that reason, it is significant to identify various and fundamentally different training courses (e.g., in educational modules in Educational Science or Didactics), in which one could also focus on ESD-specific competencies of teachers.

\section{Conflicts of Interest}

The authors declare no conflict of interest.

\section{References and Notes}

1. Plan d'études romand. Available online: http://www.plandetudes.ch (accessed on 12 November 2013).

2. Lehrplan 21. Available online: http://www.lehrplan21.ch (accessed on 12 November 2013).

3. Corney, G.; Reid, A. Student teachers' learning about subject matter and pedagogy in education for sustainable development. Environ. Educ. Res. 2007, 13, 33-54.

4. Fien, J. Education for Sustainability: Reorientating Australian Schools for a Sustainable Future; Tela: Australian Conservation Foundation: Melbourne, Australia, 2001.

5. Künzli David, C.; Bertschy, F. Education for Sustainable Development: Conceptual Foundations, Pedagogical Structure and Practical Implementation. In Education for Sustainable Development-European Approaches; Stoltenberg, U., Holz, V., Eds.; VAS Verlag für akademische Schriften: Bad Homburg, Germany, 2012; pp. 33-53.

6. De Haan, G. The BLK '21' programme in Germany: A Gestaltungskompetenz-based model for education for sustainable development. Environ. Educ. Res. 2007, 12, 19-32.

7. Summers, M.; Corney, G.; Childs, A. Student teachers' conceptions of sustainable development: the starting-point of geographers and scientists. Educ. Res. 2004, 46, 163-182. 
8. Künzli David, C. Zukunft mitgestalten lernen. Bildung für eine nachhaltige EntwicklungDidaktisches Konzept und Umsetzung in der Grundschule (in German); Haupt: Bern, Switzerland, 2007.

9. Kunter, M.; Baumert, J.; Blum, W.; Klusmann, U.; Krauss, S.; Neubrand, M. Cognitive Activation in the Mathematics Classroom and Professional Competence of Teachers; Springer: New York, NY, USA, 2013.

10. Jank, W.; Meyer, H. Didaktische Modelle (in German); Cornelsen: Berlin, Germany, 2002.

11. Without discussing the term of competence any further [44], we state that we refer to this term as "the personal preconditions for successful coping with specific situational requirements" ([25], p. 31). With regard to teacher education, this refers to abilities that a teacher must have [45]. In a narrower sense, competence refers to knowledge and ability; in the broader sense of action competence [40] it also encompasses motivational, volitional, metacognitive and self-regulative aspects.

12. Sleurs, W. Competencies for ESD (Education for Sustainable Development) Teachers: A Framework to Integrate ESD in the Curriculum of Teacher Training Institutes. Available online: http://www.unece.org/fileadmin/DAM/env/esd/inf.meeting.docs/EGonInd/8mtg/CSCT\%20Handbo ok_Extract.pdf (accessed on 24 October 2013).

13. United Nations Economic Commission for Europe. Learning for the Future: Competences in Education for Sustainable Development. Available online: http://www.unece.org/fileadmin/DAM/ env/esd/ESD_Publications/Competences_Publication.pdf (accessed on 24 October 2013).

14. Adomssent, M.; Hoffmann, T. The Concept of Competencies in the Context of Education for Sustainable Development. Available online: http://esd-expert.net/materials/concept-papers/ (accessed on 25 October 2013).

15. The CSCT model is fundamentally based on the KOM-BiNE model [46,47]. This is why this model is not included in our analysis.

16. Klafki, W. Characteristics of a Critical-Constructive Didaktik. In Didaktik and/or Curriculum: An International Dialogue; Gundem, B.B., Hopmann, S., Eds.; Peter Lang: New York, NY, USA, 1998; pp. 307-330.

17. Elmose, S.; Roth, W.-M. Allgemeinbildung: Readiness for living in risk society. J. Curriculum Stud. 2005, 37, 11-34.

18. Wals, A. Shaping the Education of Tomorrow: 2012 Report on the UN Decade of Education for Sustainable Development; UNESCO: Paris, France, 2012.

19. In the context of the CSCT model the term skills is used beside the term competency. Unfortunately, the CSCT model does only insufficiently and inconsistently explain the distinction and the relation between skills and competencies

20. This focus on professionalization becomes evident even through the various concepts that try to grasp teachers' competencies, cf. for example, Baumert, J.; Kunter, M. Stichwort: Professionelle Kompetenz von Lehrkräften. Zeitschrift für Erziehungswissenschaft 2006, 9, 469-520.

21. NBPTS - National Board for Professional Teaching Standards. What teachers should know and be able to do. Available online: http://www.nbpts.org/sites/default/files/documents/certificates/ what_teachers_should_know.pdf(accessed on 25 October 2013). 
22. Bromme, R. Teacher expertise. In International Encyclopaedia of the Social and Behavioral Sciences; Baltes, P.B., Smelser, N.J., Eds.; Elsevier: Amsterdam, The Netherlands, 2001; Volume 26, pp. 15459-15465.

23. Müller, U. Der Mensch im Mittelpunkt: Bildung für eine nachhaltige Entwicklung benötigt die Klärung des Bildungsbegriffs. Politische Ökologie 2000, 12, 8-11, (in German).

24. United Nations Educational Scientific and Cultural Organization: Educating for a Sustainable Future: A Transdisciplinary Vision for Concerted Action; EPD-97/CONF.401/CLD.1. Available online: http://www.unesco.org/education/tlsf/mods/theme_a/popups/mod01t05s01.html (accessed on 15 November 2013).

25. Baumert, J.; Kunter, M. Das Kompetenzmodell von COACTIV. In Professionelle Kompetenz von Lehrkräften (in German); Kunter, M., Baumert, J., Blum, W., Klusmann, U., Krauss, S., Neubrandt, M., Eds.; Waxmann: Berlin, Germany, 2011; pp. 29-53.

26. Vare, P.; Scott, W. Learning for a Change: Explorating the Relationship Beetwen Education and Sustainable Development. J. Educ. Sustain. Dev. 2007, 1, 191-198.

27. Bertschy, F.; Künzli David, C. Aufgaben und Möglichkeiten von Bildungsinstitutionen im Kontext Nachhaltiger Entwicklung. In Die Zeit der Pädagogik. Zeitperspektiven im erziehungswissenschaftlichen Diskurs. Festschrift für Walter Herzog (in German); Schönbächler, M.-T., Becker, R., Hollenstein, A., Osterwalder, F., Eds.; Haupt: Bern, Switzerland, 2010; pp. 211-225.

28. Heid, H. Ökologische Pädagogik? Kritische Anmerkungen zu den Voraussetzungen umweltpädagogischen Denkens und Handelns. In Deutsche Gegenwartspädagogik, III: Interdisziplinäre Verflechtungen und intradisziplinäre Differenzierungen (in German); Borelli, M., Ruhloff, J., Eds.; Schneider: Hohengehren, Germany, 1998; pp. 3-25.

29. Lovlie, L.; Standish, P. Introduction: Bildung and the idea of a liberal education. J. Philos. Educ. 2002, 36, 317-340.

30. Peters, R.S. Ethics and Education; Allen \& Unwin: London, UK, 1966.

31. Vare and Scott [26] distinguish ESD 1 (instrumental competencies for the implementation of concrete goals of sustainable development) and ESD 2 (specific competencies for sustainable development) more by their respective effects rather than by superordinate competencies and thus their underlying purpose. They thus draw a different conclusion, which is that ESD 1 and ESD 2 are two sides of the same coin (in the sense of Yin and Yang), and that they are to be considered complementary at each stage of education.

32. In this understanding, the vocational nature is not only inherent to vocational training but even to tertiary level education (Universities of Applied Sciences as well as Universities).

33. In our view, when it comes to the formulation of competence components for educators we should distinguish between subject teachers (at Secondary I and II level) and educators who teach different subjects (as it is usual in kindergarten and primary school, for example). This is particularly important with regard to the perspective-integrating subject "Sachunterricht" - a subject that incorporates aspects of the humanities, social sciences and life sciences. The necessary competence components for the implementation of BNE are inherently different (cf. also Künzli David and Bertschy [5] or [35]). Subject teachers, for example, absolutely need to have the ability for interdisciplinary work with other subject teachers. 
34. "ZMiLe"-Zukunft mitgestalten lernen (learning to help shape the future). A development and research project of the Institute for Pre-Primary and Early Primary Education, FHNW School of Education and the Institute for Pre-Primary and Primary Education, IVP NMS of the School of Education Berne. ZMiLe encompasses a range of teaching materials for BNE for kindergarten and primary school, see, http://www.zmile.ch (accessed on 14 November 2013).

35. Bertschy, F.; Gingins, F.; Künzli David, C.; Di Giulio, A.; Kaufmann-Hayoz, R. Bildung für eine Nachhaltige Entwicklung in der obligatorischen Schule. Available online: http://edudoc.ch/record/ 24373/files/BNE_Schlussbericht_2007_d.pdf?ln=enversion=1 (accessed on 14 November 2013).

36. Baumert, J.; Kunter, M.; Blum, W.; Brunner, M.; Voss, T.; Jordan, A.; Klusmann, U.; Krauss, S.; Neubrand, M.; Tsai, Y.-M. Teachers' mathematical knowledge, cognitive activation in the classroom, and student progress. Am. Educ. Res. J. 2010, 47, 133-180.

37. Shulman, L.S. Those who understand: Knowledge growth in teaching. Educ. Res. 1986, 15, 4-14.

38. Shulman, L.S. Knowledge and teaching: Foundation of the new reform. Harward Educ. Rev. 1987, $57,1-22$.

39. Shulman, L.S. Theory, practice, and the education of professionals. Elem. School. J. 1998, 98, 511-526.

40. Weinert, F.E. Leistungsmessungen in Schulen (in German); Beltz: Weinheim, Germany, 2001.

41. Knowledge and ability can be distinguished by means of their validity claim and their justification claim of beliefs [20,25]. However, the examination of scientific knowledge in the context of offers for education and further education can lead to the alteration of declarative and procedural knowledge, as well as beliefs.

42. Moore, J. Barriers and pathways to creating sustainability education programs: Policy, rhetoric and reality. Environ. Educ. Res. 2005, 11, 537-555.

43. Dawe, G.; Jucker, R.; Martin, S. Sustainable development in higher education: Current practice and future developments. Available online: http://www.heacademy.ac.uk/resources/detail/ sustainability/dawe_report_2005 (accessed on 24 October 2013).

44. Morgensen, F.; Schnack, K. The action competence approach and the 'new' discourse of education for sustainable development, competence and quality criteria. Environ. Educ. Res. 2010, 16, 59-74.

45. Oelkers, J. Wie lernt man den Beruf? Zum Systemwechsel in der Lehrerbildung. Wirtschaft und Wissenschaft 2006, 1, 44-55, (in German).

46. Rauch, F.; Steiner, R. Competences for education for sustainable development in teacher education. Center Educ. Policy Stud. J. 2013, 3, 9-24.

47. Rauch, F.; Streissler, A.; Steiner, R. Kompetenzen für Bildung für Nachhaltige Entwicklung (KOM-BiNE). Konzepte und Anregungen für die Praxis (in German); Bundesministerium für Unterricht, Kunst und Kultur: Wien, Austria, 2008.

(C) 2013 by the authors; licensee MDPI, Basel, Switzerland. This article is an open access article distributed under the terms and conditions of the Creative Commons Attribution license (http://creativecommons.org/licenses/by/3.0/). 